\title{
PELUANG DAN TANTANGAN PROVINSI JAWA TENGAH MENGHADAPI BONUS DEMOGRAFI DAN TERCIPTANYA GENERASI EMAS : KAJIAN ANALISIS ASPEK PENDIDIKAN, KESEHATAN, KETENAGAKERJAAN DATA KEPENDUDUKAN 2018
}

\section{The Opportunities and Challenges of Central Java Province Facing} Demographic Bonus and Creation of Gold Generation: Study of Education Aspects, Health, Employment, Population Data 2018

\author{
Retno Setyowati $^{1)}$, Mujahidatul Musfiroh ${ }^{2)}$, Najib $^{3)}$ \\ ${ }^{1), 2)}$ Pusat Penelitian Kependudukan LPPM UNS \\ ${ }^{3)}$ BBKBN Provinsi Jawa Tengah \\ email:miedhamus@gmail.com
}

\begin{abstract}
ABSTRAK
Latar Belakang: Provinsi Jawa Tengah merupakan provinsi dengan jumlah penduduk terbesar ketiga di Indonesia dengan dampak demografi yang sangat bervariasi, baik dari bidang pendidikan, kesehatan, dan ketenagakerjaan. Tujuan penelitian ini yaitu menganalisa data pendidikan, kesehatan, dan ketenagakerjaan Provinsi Jawa Tengah dalam Survei Demografi dan Kesehatan Indonesia 2017 (SDKI 2017) dikaitkan dengan dampak demografi penduduk.

Metode: Penelitian ini menggunakan metode analisis data sekunder dari data SDKI 2017. Sampel penelitian dan teknik pengambilan sampel dalam penelitian ini sesuai dengan rancangan dan desain sampel dalam SDKI 2017. Instrumen dalam penelitian ini yaitu kuesioner SDKI 2017.

Hasil: Gambaran tingkat pendidikan responden yaitu $41 \%$ responden wanita dan $43 \%$ responden pria yang berusia 15-45 tahun mempunyai pendidikan SLTA atau lebih tinggi. Tingkat kesehatan menunjukan kepedulian responden memiliki jaminan kesehatan yaitu sebesar 58\% responden wanita dan 57\% responden pria. Kajian ketenagakerjaan responden menunjukan tenaga kerja yang berusia 15-49 tahun yaitu 98\% tenaga kerja pria dan 53\% tenaga kerja wanita.

Kesimpulan: Penelitian menunjukan bahwa tingkat responden sebagian besar masih dalam kategori menengah dan kepedulian responden terhadap kualitas kesehatan penduduk masih rendah. Aspek ketenagakerjaan menunjukan bahwa responden yang bekerja sudah memasuki usia produktif namun masih didomininasi tenaga kerja pria. Belum optimal keterlibatan wanita dalam menunjang aspek ekonomi.
\end{abstract}

Kata Kunci: Pendidikan, Kesehatan, Ketenagakerjaan, Provinsi Jawa Tengah 


\section{ABSTRACT}

Background: Central Java Province is the province with the third largest population in Indonesia with very varied demographic impacts, both in the fields of education, health and employment. The purpose of this study is to analyze education, health and employment data in Central Java Province in the 2017 Indonesian Demographic and Health Survey (IDHS 2017) associated with population demographic impacts.

Method: This study used a secondary data analysis method from the 2017 IDHS data. The research samples and sampling techniques in this study were in accordance with the sample design and design in the IDHS 2017. The instruments in this study were the 2017 IDHS questionnaire.

Results: The description of the respondent's education level is $41 \%$ of female respondents and $43 \%$ of male respondents who receive 15-45 years of having a high school education or higher. The health level answers the concerns of respondents having health insurance, which is equal to $58 \%$ of female respondents and $57 \%$ of male respondents. The employment assessment of the respondents shows that workers show 15-49 years old 98\% male workers and 53\% female workers.

Conclusion: Research shows that the majority of respondents are still in the middle category, the respondents' concern for the health quality of the population is still low. The employment aspect shows that respondents who work have entered the productive age, but are still dominated by male workers, not yet optimal involvement of women in supporting economic aspects

Keywords: Education, Health, Employment, Central Java Province

\begin{tabular}{l}
\hline LATAR BELAKANG \\
\hline Jumlah penduduk Indonesia pada tahun \\
2017 berjumlah 261.9 juta mengalami \\
peningkatan 3.2 juta dari tahun 2016 . \\
Laju pertumbuhan penduduk di Indonesia \\
pada tahun 2017 yaitu $1.34 \%$. Kondisi \\
penduduk di Indonesia semakin \\
meningkat dan bersiap menuju bonus \\
demografi. Bonus demografi di Indonesia \\
terjadi karena peningkatan pertumbuhan \\
penduduk usia kerja. Rentang usai 20-54 \\
tahun merupakan rentang usia dengan \\
jumlah tertinggi. Rentang usia 20-54 \\
tahun merupakan usia kerja. Demografi \\
penduduk Indonesia berdasarkan usia \\
kerja menunjukan bahwa persentase \\
bekerja terhadap angkatan kerja yaitu \\
$94.50 \%$ persentase angkatan kerja \\
terhadap usia kerja yaitu $66.67 \%$. Tahun \\
2017 angka pengangguran di Indonesia \\
terus menurun hingga 5.3\% dari tahun \\
2015 . Angka pengangguran yang relatif \\
menurun tidak menunjukan berkurangnya \\
tantangan yang dihadapi oleh penduduk
\end{tabular}

Indonesia. Kondisi ketenagakerjaan dikaji dari tingkat partisipasi angkatan kerja penduduk Indonesia sebesar $66.7 \%$, tingkat pengangguran terbuka sebesar $5.5 \%$. Jumlah angkatan kerja menurut pendidikan yaitu 32 juta penduduk yang bekerja mempunyai pendidikan tertinggi Sekolah Dasar (SD) dan terendah pada angkatan kerja dengan tingkat pendidikan terakhir diploma. ${ }^{[1]}$

Kondisi ketenagakerjaan terkait produktivitas, kualitas kerja, gender, dan disparitas masih menjadi kendala dalam meningkatkan kesejahteraan penduduk Indonesia. Kesejahteraan penduduk Indonesia ditentukan oleh kualitas sumber daya manusia Indonesia. Aspek yang mempengaruhi kualitas sumber daya manusia yaitu pendidikan dan kesehatan. Kualitas pendidikan dapat dikaji dengan melihat angka melek huruf penduduk Indonesia. ${ }^{[2]}$ Angka melek huruf usia $>15$ tahun yaitu 95.5\%. Angka putus sekolah untuk penduduk usia 10-19 tahun di daerah perkotaan yaitu $25.66 \%$ 
dan di daerah pedesaan yaitu $34.42 \%$. Berdasarkan jenis kelamin, angka putus sekolah yaitu $28.92 \%$ pada penduduk laki-laki usia 7-24 tahun dan 28.43\% untuk penduduk wanita usia 7-24 tahun. Persentase penduduk miskin sebesar $10.6 \%$ dan Indeks Pembangunan Manusia sebesar $70.8 \%$. $^{[1]}$

Provinsi Jawa Tengah merupakan Provinsi dengan jumlah penduduk terbesar ketiga di Indonesia yaitu 34.3 ribu dengan laju pertumbuhan penduduk sebesar $0.71 \%$. Jumlah angkatan kerja di Provinsi Jawa Tengah yaitu 18 juta dengan jumlah pengangguran 8.23 ribu. Kondisi ketenagakerjaan di Provinsi Jawa Tengah yaitu persentase penduduk yang bekerja terhadap angkatan kerja yaitu 95.43\% dan persentase angkatan kerja terhadap penduduk usia kerja yaitu 69.11\%. Angkatan kerja di Provinsi Jawa Tengah tertinggi yaitu penduduk dengan pendidikan tertinggi Sekolah Dasar. Jumlah penduduk yang bekerja terbanyak pada usia 35-44 yaitu 4.185.706. ${ }^{[1][3]}$

Kajian ketenagakerjaan di Provinsi Jawa Tengah yaitu persentase penduduk Provinsi Jawa Tengah yang berusia 15-49 tahun yang bekerja yaitu $98 \%$ untuk pria dan $53 \%$ untuk wanita, berdasarkan tempat tinggal tidak menunjukan perbedaan persentase antara penduduk perkotaan dan pedesaan. Menurut tingkat pendidik, persentase terbesar penduduk yang bekerja memiliki pendidikan tertinggi tidak sekolah untuk wanita dan tidak tamat SD dan tidak tamat SLTA untuk pria. Tingkat kesehatan penduduk Jawa Tengah ditunjukan dengan persentase penduduk yang mengalami keluhan kesehatan pada tahun 2017 sebanyak $32.72 \%$, lebih tinggi dari ratarata persentase penduduk yang mengalami keluhan kesehatan di Indonesia yaitu $28.62 \% .^{[1],[3]}$ Derajat kesehatan ditunjukan dengan persentasi merokok, status kesehatan ibu, fertilitas pada remaja, Keluarga Berencana, status kesehatan bayi dan balita, pengetahuan, sikap, dan perilaku tentang HIV AIDS dan isu terkait. ${ }^{[4]}$ Jumlah penduduk Provinsi Jawa Tengah terbanyak mempunyai tingkat pendidikan tertinggi yaitu Sekolah Menengah Kejuruan yaitu 59.342. Jumlah sekolah di Provinsi Jawa Tengah yaitu 14.013 sekolah dengan jumlah guru 47 ribu. ${ }^{[1],[3]}$

\section{SUBJEK DAN METODE}

Penelitian ini menggunakan metode analisis data sekunder SDKI 2017 Provinsi Jawa Tengah. Karakterisitik responden dalam penelitian ini disesuaikan dengan karakteristik responden pada survei yang dilakukan oleh BKKBN Provinsi Jawa Tengah yaitu usia responden 15-54 tahun, dengan status perkawinan : belum kawin, kawin, hidup bersama, cerai hidup, cerai mati, bertempat tinggal di perkotaan dan pedesaan, pendidikan responden : tidak sekolah, tidak tamat $\mathrm{SD}$, tamat $\mathrm{SD}$, tidak tamat SLTA, tamat SLTA, Perguruan Tinggi. Penelitian dilakukan di seluruh Kabupaten dan Kota di Provinsi Jawa Tengah dan dilakukan selama kurun waktu satu bulan pada tahun 2017. Tahapan penelitian, yaitu :

1. Menetapkan (mencari-temukan) sumber data atau informasi yang akan dianalisis.

2. Mengumpulkan data yang sudah tersedia dalam dokumen.

3. Menormalisasikan data yang diperlukan dan mengumpulkan data dari berbagai sumber yang setara.

4. Menganalisis data, misalnya : menghitung, mentabulasi, memetakan data kuantitatif dan membandingkan berbagai peraturan.

5. Menelaah hasil analisis dengan peraturan untuk membuat kebijakan.

Pendekatan yang digunakan dalam penelitian ini yaitu mengumpulkan data sekunder, dilanjut menelaah untuk mencermati variabel-variabel atau aspekaspek yang ada dalam data yang akan dianalisis. Selanjutnya menghubungkan 
berbagai aspek atau variabel yang berkaitan dengan data yang analisis.

\section{HASIL}

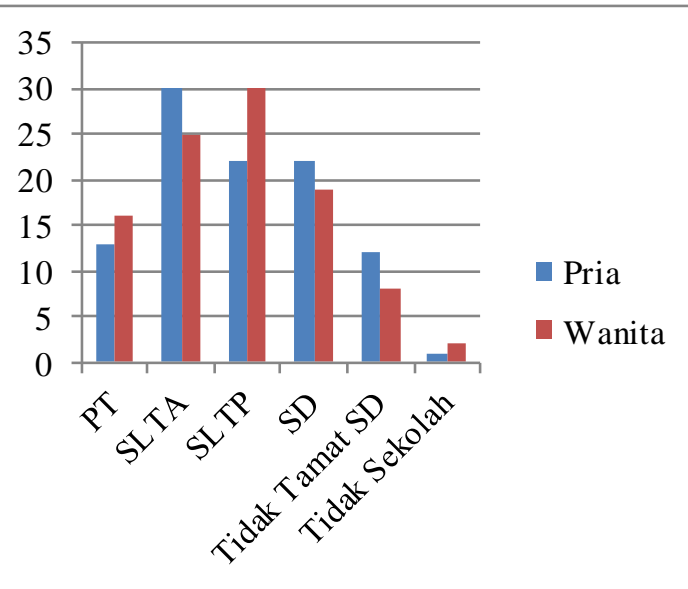

Gambar 1. Persentase Tingkat Pendidikan Responden ${ }^{[4]}$

Tingkat pendidikan responden mayoritas (30\%) tamatan SLTA untuk responden pria dan tamatan SLTP untuk responden wanita.

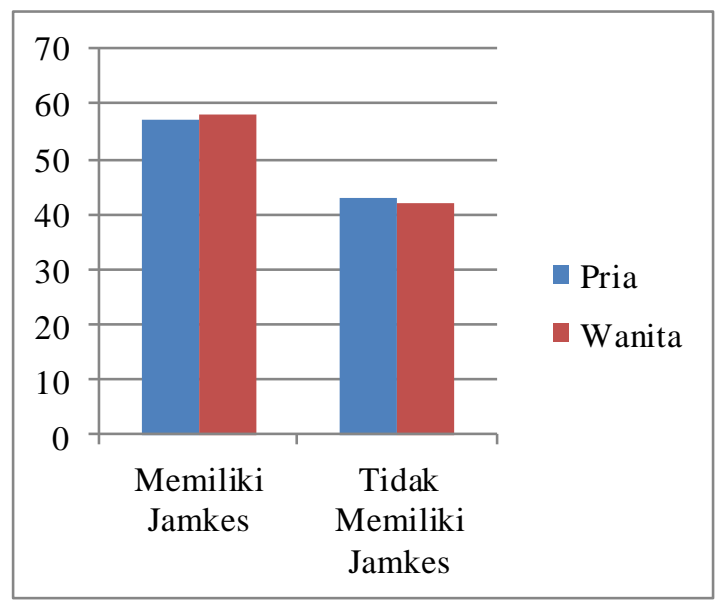

Gambar 2. Persentase Kepemilikan Jaminan Kesehatan ${ }^{[4]}$

Kepemilikan jaminan kesehatan sebagai bentuk kepeduliaan terhadap kualitas kesehatan antara responden pria dan wanita memiliki persentase yang hampir sama yaitu $57 \%$ dan $58 \%$.

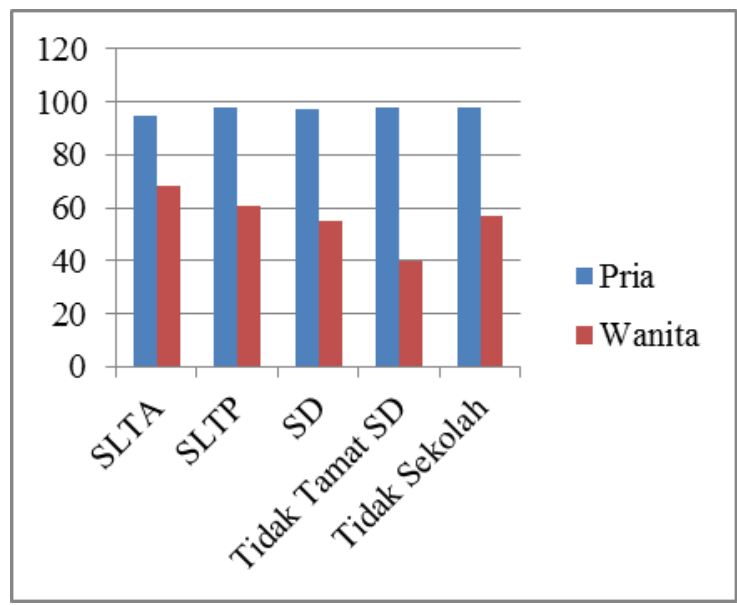

Gambar 3. Persebaran Ketenagakerjaan Responden menurut Pendidikan ${ }^{[4]}$

Responden yang bekerja mayoritas (98\%) responden pria. Tingkat pendidikan responden yang bekerja yaitu tidak sekolah untuk responden wanita $(68 \%)$ dan tidak tamat SD, SLTP dan SLTA untuk responden pria (98\%).

\section{PEMBAHASAN}

Hasil penelitian menunjukan bahwa tingkat pendidikan responden mayoritas (30\%) tamatan SLTA untuk responden pria dan tamatan SLTP untuk responden wanita. $^{[4]}$ Pendidikan merupakan hal penting bagi setiap negara untuk mewujudkan kesejahteraan rakyat. ${ }^{[5]}$ Pendidikan berperan penting dalam kemajuan peradaban dan kebudayaan suatu bangsa. Semakin tinggi tingkat pendidikan masyarakat suatu negara menyebabkan kemajuan pembangunan dan kehidupan masyarakat untuk mencapai kesejahteraan. ${ }^{[6]}$

Sistem pendidikan di Indonesia diselenggarakan melalui jalur, jenjang, dan jenis pendidikan. Berdasarkan sistem pendidikan di Indonesia, tingkat pendidikan responden termasuk dalam kategori pendidikan jalur formal dengan jenjang pendidikan menengah. Sistem pendidikan formal yang dilaksanakan di Indonesia berdasarkan Standart Nasional Pendidikan. Standart Nasional Pendidikan menunjukan arah peningkatan kualitas pendidikan Indonesia yang lebih jelas dan 
terarah. Kualitas pendidikan yang telah tersusun dengan jelas dan terarah dapat menjamin kualitas lulusan yang berkualitas. Responden yang memiliki kategori pendidikan formal dengan jenjang menengah menunjukan bahwa responden memiliki kualitas yang cukup baik. Tingkat pendidikan rakyat uatu negara menunjukan kualitas sumber daya manusia. ${ }^{[6]}$ Sumber daya manusia yang berkualitas diperlukan dalam menopang pengembangan ekonomi berbasi pengetahuan. Ketersediaan sumber daya manusia yang berkualitas menentukan kemampuan bangsa dalam memasuki kompetensi global dan ekonomi pasar bebas yang menuntut daya saing tinggi. Tingkat pendidikan responden dengan kategori formal menengah dapat menjadi modal bangsa Indonesia khususnya Provinsi Jawa Tengah untuk meraih keunggulan dalam persaingan global. ${ }^{[7]}$

Kualitas kesehatan responden dalam penelitian ini ditunjukan dengan kepemilikan jaminan kesehatan. Kepemilikan jaminan kesehatan menunjukan kepedulian responden dalam mempertahankan kualitas kesehatan. Responden mayoritas (>50\%) telah memiliki jaminan kesehatan. Jaminan kesehatan merupakan program jaminan sosial yang diselenggarakan secara nasional dengan tujuan untuk menjamin agar peserta dan anggota keluarga memperoleh manfaat pemeliharaan kesehatan dan perlindungan dalam memenuhi kebutuhan dasar kesehatan. Jaminan kesehatan mewujudkan peningkatan kualitas kesehatan masyarakat melalui program pemeliharaan kesehatan, pencegahan penyakit, pengobatan, perawatan dan rehabilitasi medis. ${ }^{[8]}$ Selain kepemilikan jaminan kesehatan, kualitas kesehatan terkait dengan jaminan kesehatan yaitu sumber daya pelaksana program jaminan kesehatan ditingkat pelayanan kesehatan dan sarana prasara pendukung. Jaminan kesehatan yang dimiliki akan bermanfaat secara optimal jika didukung dengan kualitas sumber daya pelaksana program jaminan kesehatan yang memadai dan sarana prasarana yang berkembang seiring dengan perkembangan kebutuhan masyarakat. ${ }^{[9],[10]}$

Sumber daya manusia dengan kualitas kesehatan baik dapat menciptakan manusia yang tangguh, mandiri dan berkualitas. Sumber daya manusia yang berkualitas menjadi modal pembangunan nasional. Pembangunan nasional yang optimal dapat tercapai seiring dengan pembangunan kesehatan masyarakat. ${ }^{[11]}$ Sumber daya manusia yang berkualitas dapat meningkatkan daya saing tenaga kerja. Semakin tinggi kualitas manusia semakin tinggi daya saing untuk memperoleh pekerjaan. ${ }^{[12]}$

Hasil penelitian mengenai ketenagakerjaan menunjukan bahwa mayoritas responden pria (98\%) berstatus sebagai pekerja. Responden yang bekerja masih didominasi responden dengan tamatan SD, SLTP dan SLTA. Tenaga kerja memiliki peran penting dalam proses pembangunan ekonomi. Tenaga kerja dengan kualifikasi pendidikan tinggi dapat meningkatkan daya saing dalam pembangunan perekonomian.

Indikator daya saing tenaga kerja yaitu tingkat produktivitas. Kuantitas tenaga kerja Indonesia yang besar yang tidak diikuti oleh peningkatan kualitas sumber daya manusia menyebabkan rendahnya produktivitas tenaga kerja Indonesia, sehingga mempengaruhi daya saing perekonomian Indonesia. ${ }^{[12]}$ Peningkatan kuantitas tenaga kerja tanpa perluasan kesempatan kerja dapat menyebabkan peningkatan jumlah pengangguran dan peningkatan daya saing ketenagakerjaan. Tingkat pengangguran di Indonesia semakin meningkat dari tahun ke tahun sehingga peningkatan daya saing ketenagakerjaan juga semakin besar. ${ }^{[13]}$ Peningkatan daya saing ketenagakerjaan dapat dilakukan dengan menerapkan program usaha kecil menengah (UKM).

Program UKM dapat mengatasi permasalahan peningkatan kuantitas 
tenaga kerja dengan kualitas yang cukup. Program UKM dapat menjadi solusi untuk mengurangi angka penganguran akibat peningkatan pertumbuhan penduduk Indonesia. $^{[14]}$

\section{SIMPULAN}

1. Kondisi demografi mempengaruhi permasalahan pendidikan, kesehatan dan ketenagakerjaan.

2. Tingkat pendidikan responden dalam kategori formal pada jenjang menengah.

3. Tingkat kesehatan responden dalam kategori baik, ditunjukan dengan kesadaran responden untuk memiliki jaminan kesehatan.

4. Ketenagakerjaan menunjukan peningkatan kuantitas dan belum diikuti peningkatan kualitas.

5. Peningkatan kualitas sumber daya manusia sebagai modal pembangunan perlu dilakukan dengan peningkatan pendidikan, kesehatan dan kualitas manusia sebagai tenaga kerja.

\section{SARAN}

Kajian mengenai data SDKI 2017 perlu dilakukan secara kuantitatif komprehensif.

\section{DAFTAR PUSTAKA \\ 1. Badan Pusat Statistik Indonesia. Statistik Indonesia. Statistical Yearbook of Indonesia 2018; 2018.}

2. Organisasi Perburuhan Internasional. Laporan Ketenagakerjaan Indonesia. Memanfaatkan Teknologi untuk Pertumbuhan dan Penciptaan Lapangan Kerja; 2017.

3. Tengah BPSPJ. Provinsi Jawa Tengah dalam Angka 2018; 2018.

4. BKKBN, BPS, Kemenkes, USAID. Survei Demografi dan Kesehatan 2017; 2017.

5. Megawanti P. 2012. Meretas Permasalahan Pendidikan Di Indonesia. Formatif. 2012;2(3):22734.

6. Raharjo SB. Evaluasi Trend Kualitas Pendidikan di Indonesia. J Penelit
Dan Eval Pendidik [Internet]. 2012;16(2):246-67. Available from: https://journal.uny.ac.id/index.php/jpe p/article/view/1129; 2012.

7. Suryana S. Permasalahan Mutu Pendidikan dalam Perspektif Pembangunan Pendidikan. Edukasi [Internet]. 2017;2(1):109-21. Available from: https://journal.unnes.ac.id/nju/index.p hp/edukasi/article/view/971/908; 2017.

8. Putri AE. Paham SJSN. Sistem Jaminan Sosial NAsional [Internet]. Jakarta: Friedrich Ebert Stiftung Kantor Perwakilan Indonesia; Available from: https://library.fes.de/pdffiles/bueros/indonesien/11023.pdf; 2014.

9. Saputra M, Marlinae L, Rahman F Rosadi D. Program Jaminan Kesehatan Nasional dari Aspek Sumber Daya Manusia Pelaksana Pelayanan Kesehatan. J Kesehat Masy. 2012;1(1):1-11; 2012.

10. Eryando T, Afriansyah E, Susanna D, Wulandari D, Agustini T. Program Pembangunan Kesehatan Masyarakat BErbasi Digital di Daerah Pesisir Kecamatan Palabuhanratu Tahun 2017. Charity. 2018;01(01):1-11.

11. Pasaribu RM. Solusi dalam mengatasi masalah pembangunan kesehatan masyarakat di indonesia. J Ilm Dunia Ilmu. 2015;1(2):1-9.

12. Adam L. Membangun Daya Saing Tenaga Kerja Indonesia melalui Peningkatan Produktivitas. J Kependud Indones. 2016;11(2):13-9.

13. Kementerian Tenaga Kerja dan Transmigrasi. Perkembangan Ketenagakerjaan di Indonesia; 2011.

14. Dongoran FR, Nisa K, Sihombing M, Purba LD. Analisis Jumlah Pengangguran dan Ketenagakerjaan terhadap Keberadaan Usaha Mikro Kecil dan Menengah di Kota Medan. J Edutech. 2016;2(2):59-72; 2016. 
PLACENTUM Jurnal Ilmiah Kesehatan dan Aplikasinya, Vol 7(2) 2019 